\title{
Melanoma of the Conjunctiva pT2b TNM
} Finding v7

National Cancer Institute

\section{Source}

National Cancer Institute. Melanoma of the Conjunctiva pT 2b TNM Finding v7. NCI

Thesaurus. Code C88625.

Melanoma of the palpebral, forniceal, or caruncular conjunctiva with tumor measuring more than $0.5 \mathrm{~mm}$ but not more than $1.5 \mathrm{~mm}$ in thickness with invasion of the substantia propria. (from AJCC 7th Ed.) 